\title{
GENESIS OF DAWSONITE DEPOSITS IN THE PRIPYAT TROUGH
}

\section{S. Konischev}

\section{ГЕНЕЗИС ЗАЛЕЖЕЙ ДАВСОНИТА В ПРИПЯТСКОМ ПРОГИБЕ В.С. Конищев}

It was shown that dawsonite deposits in Carboniferous strata of the Pripyat Troug had been formed in compensation synclines under lacustrine conditions as a result, of action soda solutions upon aluminosilicate rocks of the crust of weathering. Soda solution formed as a result of dissolution of caprocks with oil in the crests of salt diapirs.

Key words: dawsonite, Pripyat Trough, compensation synclines, salt diapirs, soda solutions, aluminosilicate, crust of weathering.

Установлено, что залежи давсонита в отложениях бобриковского горизонта визейского яруса нижнего карбона в Припятском прогибе формировались в компенсационных синклиналях в озерных водоемах в результате воздействия на переотложенные алюмосиликатные породы коры выветривания содовых растворов, образованных при растворении пород нефтегазонасыщенной брекчии кепрока в сводах соляных диапиров.

Ключевые слова: давсонит, Припятский прогиб, компенсационные синклинали, соляные диапиры, содовые растворы, алюмосиликатныс породы, кора выветривания.

Давсонит, карбонат алюминия и натрия, является сырьем для получении алюминия, соды и цемента. Давсонит был впервые обнаружен в Припятском прогибе в 1971 г. в радаевских отложениях визейского яруса нижнего карбона при опробовании керна Осташковичской скв. 11-к из инт. 1185-1219 м [6]. При ревизионно-тематических работах горизонты давсонита были выделены в отложениях бобриковского горизонта в трех скважинах Заозерного поднятия (скв. 6у, 9у, 93).

Бобриковский горизонт яснополянского надгоризонта визейского яруса нижнего карбона выделяется в верхней части каолиновой толщи как богутичская свита. Горизонт залегает на пестроцветных песчано-глинистых породах Малиновского надгоризонта (гостовская свита) и перекрыт темно-серыми до черных углистыми глинами тульского горизонта. Мощность горизонта на Заозерной площади изменяется от 7 до 46 м [9]. Нижняя часть бобриковского горизонта сложена песчаными породами, верхняя - глинисто-алевролитовыми белыми и розовыми каолиновыми породами, часто переходящими в чистый каолин, с редкими остатками растений, с прослоями бокситов, бокситоподобных глин, давсонита и бурых углей. Эти отложения, выделяемые в качестве каолиновой угленосно-бокситоносной субформации, накапливались в континентальных условиях и крупных пресноводных водоемах при жарком, переменно аридном и влажном климате, благоприятном для образования латеритных кор выветривания, заболоченных водоемов, накопления прослоев углей и углистых глин.

На Заозерном месторождении в верхней глинистой части бобриковского горизонта было разведано две залежи: Северная и Южная, соответственно на северном и южном крыльях Заозерной антиклинали. Каждая из них состоит из двух линз: западной и восточной. Средняя мощность рудовмещающей глинистой толщи на обоих склонах Заозерного поднятия при-мерно одинаковая: 10,2 м на северном, 10,8 м - на южном. На участках с выявленной давсонитовой минерализацией ее мощность возрастает: на северном склоне от 10,2 (скв. 45 П) до 20,8 м (скв. 50 П) при средней мощности 16,1 м, на южном склоне мощность рудной зоны меняется от 6,5 м (скв. 6 П) до 33,7 м. (скв. 20 П) при средней величине 16,7 м. Из этого можно заключить, что благоприятные для образования давсонита условия характерны для локальных наиболее активно прогибавшихся участков бассейна осадконакопления. В рудовмещающей глинистой толще имеется несколько рудных тел, среди которых выделяется среднее, наиболее выдержанное по составу и мощности рудное тело; верхнее и нижнее рудные тела распространены ограниченно и не играют существенной роли в балансе руд. Мощность главного рудного тела изменяется от 0,4 до 9,6 м, содержание давсонита - от 10 до $77,8 \%$, при среднем содержаний 25\%. Площадь залежей колеблется от 1,25 до 5,9 км². Рудные пласты перекрываются и подстилаются каолиновыми глинами или аллитами. Залегает рудное тело па глубинах от 370 до 900 м на 5-25 м ниже кровли бобриковского горизонта [7]. 
В сводовой и присводовой частях Заозерной антиклинали рудоносная часть разреза представлена переслаиванием аллитов (3-6 прослоев) и бокситов (1-4 прослоя) с тонкодисперсными каолиновыми глинами в кровле и подошве, давсонитовая минерализация здесь отсутствует [5].

Высокоглиноземистые руды Заозерного месторождения являются смешанными породами и состоят из каолинита, боксита, давсонита и карбонатов (кальцита, сидерита, доломита).

Основным компонентом давсонит-бокситовых руд и вмещающих пород является каолинит, содержание которого изменяется от 90 до 35\% в богатых давсонитовых и давсонит-бокситовых рудах. Вторым по распространению минералом в рудных телах является давсонит. При среднем содержании 25\% для всего месторождения иногда его содержание достигает 40-45\% и более. Среднее содержание бокситовых минералов (гиббсит, нордстрандит, бемит) для рудоносной пачки составляет 7,6\%. Сопутствующими минералами являются сидерит, гематит, доломит, кальцит, кварц, пирофиллит. По сочетанию главных и сопутствующих минералов выделяются три типа (давсонитовые, бокситдавсонитовые и бокситовые) и 13 подтипов руд. Характерно присутствие в бобриковских отложениях сульфатов и галита [7]. Отмечены крупнокристаллические выделения ангидрита и на Осташковичском рудопроявлении давсонита [1].

Давсонитоные руды серые, светло-серые, красно-бурые и буровато-коричневые, массивной, брекчиевидной или бобовидной структуры, прожилковидной или гнездовидно-пятнистой текстуры, нередко пористые, кавернозные и трещиноватые. В массивных породах давсонит образует мелкие или крупные глобули игольчатого строения, их скопления располагаются беспорядочно или послойно. Часто давсонит образует сплошную массу лучистых сростков тончайших белых кристаллов. В породах с гнездовидно-пятнистой текстурой давсонит имеет спутанно-волокнистое строение. Широко развиты псевдоморфозы давсонита по другим минералам: гематиту, ангидриту, пириту, сидериту, доломиту, каолиниту, полевым шпагам, по растительным остаткам. Это свидетельствует о его более позднем образовании. Нередко он выполняет трещины или окаймляет минералы [7].

Были предложены седиментационная, постседиментационная, гидротермальная и грязе-вулканическая гипотезы генезиса давсонита. Практически все они исходят из того, что давсонит образовался в результате воздействия на алюмосиликатные породы гидрокарбонатных растворов, богатых натрием и углекислотой, но отличаются представлениями об источниках этих растворов. Согласно седиментационной гипотезе [2] содовые воды образовались при выветривании натрийсодержащих алюмосиликатов и их концентрирования вследствие сильной испарительной деятельности в периоды аридизации климата. По постседиментационной гипотезе [8] высокощелочные воды, обогащенные углекислотой и натрием, продуцировали обогащенные органическим веществом покрывающие песчано-глинистые породы тульского горизонта. Проникая в породы бобриковского горизонта, они преобразовывали алюмосиликаты в давсонит.

Согласно гидротермальной $[1,5]$ и грязевулканической [4] гипотезам эти воды являются гидротермальными и поступали с больших глубин или из меж- и подсолсвых отложений по разломам или в процессе грязевулканической деятельности. Однако следует отметить, что никаких следов грязевулканической деятельности в Припятском прогибе не обнаружено: геологические условия прогиба не благоприятны для формирования грязевых вулканов. На Заозерном поднятии все разломы затухают в нижней соленосиой толще и не проникают в надсолевые отложения через мощную глинисто-галитовую подтолщу, так что путей для миграции гидротермальных растворов в бобриковские отложения здесь нет.

При изучении залежей и рудопроявлений давсонита в Припятском прогибе не обращалось должного внимания на их тектоническую и палеотектоническую позицию. На Заозерном месторождении залежи расположены на северном и южном крыльях антиклинального поднятия типа «щита черепахи». Но в палеотектоническом плане они приурочены к вторичным компенсационным синклиналям, которые формировались на далеких крыльях соседних Николаевского и Каменского соляных поднятий в результате течения соли от их склонов к сводам. Эти компенсационные синклинали контролировали озерные водоемы, в которых накапливались бобриковские отложения увеличенной мощности. В районе Осташковичской скв. 11-к рудопроявление контролируется первичной компенсационной синклиналью, которая формировалась в радаевское время на южном склоне Осташковичского соляного поднятия. В сводах соляных массивов в это время каменная соль выходила на поверхность и подвергалась выщелачиванию. В результате этого формировалась брекчия кепрока, сложенная 
брекчированными в процессе галокинеза глинисто-карбонатными и сульфатными внутрисолевыми прослоями [3].

Установление приуроченности залежей и рудопроявлений давсонита к компенсационным синклиналям, формировавшимся на далеких склонах соляных поднятий, подтверждает представления, что они относятся к лимногенному типу и седиментогенному и раннедиагенетическому подтипам. Залежи давсонита формировались в содовых озерах под воздействием высокощелочных растворов, содержащих карбонаты и бикарбонаты натрия, на окислы и гидроокислы алюминия и алюмосиликаты коры выветривания, переотложенной в водоемах компенсационных синклиналей. Содовые воды могли формироваться в результате карстования пород верхней соленосной толщи в сводах, окружающих соляные криптодиапиры, где она в это время выходила на поверхность и подвергалась размыву с образованием брекчии кепрока, пропитанной нефтью [3].

1. Бирина Л.М. Давсонит в коре выветривания карбона Белоруссии // Литология и по-лез. ископаемые.1973. № 1. - С. 113-117.

2. Дмитриев Ф.Л. Континентальные отложения бобриковского горизонта нижнего кар-бона Припятской впадины: Автореф. дис...канд. геол.-минерал. наук.Вильнюс, 1977. - 23 с.

3. Копищев В.С. Тектонические закономерности формирования и размещения залежей давсонита в Припятском прогибе // Минерально-сырьевая база Республики Беларусь: состоя-ние и перспективы: Тез. докл. науч.-техни. конф. посвященной 70-летию БелНИГРИ, 22-24 окт. 1997 г. - Мн., 1997. - С. 107-109.

4. Кудельский А.В., Бурак В.М. Газовый режим Припятского прогиба. - Мн.: Наука и техника, 1982. - 174 с.

5. Курочка В.И., Савченко Н.А., Парибок В.И. и др. О на- правлении поисков давсонита на Заозерной площади Припятской впадины // Проблемы поисков твердых полезных ис-копаемых в БССР. - Мн., 1977. C. 21-28.

6. Курочка В.И., Фролов Г.Н., Дмитриев Ф.Л., Жукова М.А. О находке давсонита в Белоруссии // Докл. АН БССР. - 1972. - Т. 16, № 6. - С. 541-544.

7. Махнач А.С., Савченко Н.А., Чуйко Д.Г. и др. Давсонит Беларуси. - Мн.: Наука и техника, 1995. - 162 с.

8. Савченко Н.А. Условия формирования боксит-давсонитовых пород Припятского прогиба // Проблемы минералогении платформенного чехла и кристаллического фундамента БССР. - Мн., 1986. - С. 134-141.

9. Толстошсев В.И. Надсолевые девонские и каменноугольные отложения Припятского прогиба. - Мн.: Наука и техника, 1988. - 150 с.

Belarusian Resarch Geological Exploration Institute Ministry of Natural Resourses and Environment Protection, Minsk, Belarus Белорусский научно-исследовательский геологоразведочный институт Министерства природных ресурсов и защиты окружающей среды Беларуси, Минск, Беларусь 